\title{
Lesions of the sheep reproductive system found in a slaughterhouse in the state of Bahia, Brazil ${ }^{1}$
}

\author{
Reanne M.M. Silva², Juliana T.S.A. Macêdo ${ }^{3}$, Maira S.C. Lacerda ${ }^{3}$, \\ João Paulo M.V.B. Azevedo ${ }^{3}$, Jair A. Ferreira Júnior ${ }^{3}$, \\ Robson B. Cerqueira ${ }^{4}$ and Pedro Miguel O. Pedroso ${ }^{2,3 *}$ (iD
}

\begin{abstract}
Silva R.M.M., Macêdo J.T.S.A., Lacerda M.S.C., Azevedo J.P.M.V.B., Ferreira Júnior J.A., Cerqueira R.B. \& Pedroso P.M.O. 2020. Lesions of the sheep reproductive system found in a slaughterhouse in Bahia state, Brazil. Pesquisa Veterinária Brasileira 40(12):955-962. Laboratório de Patologia Veterinária, Fundação Universidade de Brasília, Campus Universitário Darcy Ribeiro, Via L4 Norte s\n, Brasília, DF, 70910-970, Brazil. E-mail: pedrosovet@yahoo.com.br

The present study aimed to evaluate and diagnose pathologies of the reproductive system of slaughtered sheep in slaughterhouses in the state of Bahia since there are few data on the subject as well as it is important to note the diagnosis of these diseases to apply appropriate control and prophylaxis measures. The research was carried out in slaughterhouses in the state of Bahia according to the "Serviço de Inspeção Federal" and "Serviço de Inspeção Estadual" for sheep slaughter. From July 2018 to February 2019, visits and monitoring of 1,072 slaughtered sheep were carried out. The animals came from 22 municipalities in the state of Bahia, aged from six to 18 months. During slaughter, the sheep reproductive systems were sectioned for evisceration and lesion collection. Additionally, epidemiological surveys related to origin, age, and race were obtained. For bacteriological examination, collections were performed with sterile scalpel slides and swabs in Stuart medium sterile tubes and refrigerated in a thermal box. For histopathological analysis, fragments were fixed in $10 \%$ formaldehyde and routinely processed for histology, stained with Hematoxylin and Eosin (HE). A study of the sheep's main pathological changes in slaughterhouses in the state of Bahia was carried out, in which 1.072 genital systems were evaluated, and 211 alterations were identified. The most affected reproductive organs were the ovaries $(65.3 \%)$, followed by the uterus (29.4\%) and uterine tubes (5.3\%). In the ovaries, the most frequent lesion was a follicular cyst (34.1\%); in the fallopian tubes, the cysts represented $3.3 \%$ of the lesions, and in the womb, endometritis was observed in $9 \%$ of the animals. Other pathologies identified in the ovaries were: luteinized cyst (2.3\%); cystic granulosa cell tumor (0.5\%); benign lesion $(0.5 \%)$; agenesis unilateral $(0.5 \%)$, in addition to other changes of little clinical significance, such as corpus luteum cysts $(11.8 \%)$ and paraovarian cysts $(15.6 \%)$. In the fallopian tubes, hydrosalpinx was observed (1\%), as well as adenoma (0.5\%), agenesis $(0.5 \%)$, and cysts (3.3\%). Uterine lesions included hydrometra (2.3\%); Cystic Endometrial Hyperplasia (CEH), abscess, and pyometra (1.4\% each); adenomyosis, womb sera petechiae, and total segmental aplasia ( $1 \%$ each); two pregnant uterus, in early pregnancy, presented pyometra $(0.9 \%)$, however, no change was observed in the fetuses; and uterine polyp (0.5\%). Ectopic pregnancy with fetal maceration $(0.5 \%)$ was observed; vaginitis occurred in $0.5 \%$ of the animals, and endometrial melanosis in 8.5\%. The high incidence of follicular cysts and endometritis are characterized as diseases that reduce the reproductive efficiency in herds, causing infertility and economic losses in production.
\end{abstract}

INDEX TERMS: Sheep, reproductive system, slaughterhouse, Brazil, ovaries, pathology, follicular cysts, endometritis.

\footnotetext{
${ }^{1}$ Received on July 21, 2020.

Accepted for publication on July 30, 2020.

Part of Doctoral Dissertation of the first author.

Graduate Program in Animal Science in the Tropics, Universidade Federal da Bahia (UFBA), Medicina Veterinária, Av. Adhemar de Barros 500, Ondina, Salvador, BA 40170-110, Brazil.
}

\footnotetext{
${ }^{3}$ Laboratório de Patologia Veterinária, Fundação Universidade de Brasília (UnB), Campus Universitário Darcy Ribeiro, Via L4 Norte $s \backslash n$, Brasília, DF 70910-970, Brazil. *Corresponding author: pedrosovet@yahoo.com.br

${ }^{4}$ Laboratório de Doenças Infecciosas, Hospital Universitário de Medicina Veterinária, Universidade Federal do Recôncavo da Bahia (UFRB), Rua Rui Barbosa 710, Cruz das Almas, BA 44380-000, Brazil.
} 
RESUMO.- [Lesões do sistema reprodutor em ovelhas de abatedouros frigoríficos no estado da Bahia.] 0 objetivo do presente trabalho foi avaliar e diagnosticar alterações do sistema reprodutor de ovelhas abatidas em abatedouros frigoríficos no estado da Bahia. A pesquisa foi realizada em abatedouros frigoríficos do estado da Bahia com Serviços de Inspeção Federal e Estadual no abate de ovinos. No período de julho de 2018 a fevereiro de 2019 foram realizadas visitas e acompanhamento do abate de 1.072 ovelhas. Os animais eram provenientes de 22 municípios do estado da Bahia, com idade entre 6 a 18 meses. Durante o abate, na evisceração foram seccionados os sistemas reprodutores das ovelhas para avaliação e coleta das lesões. Adicionalmente foram obtidos inquéritos epidemiológicos relacionados à procedência, idade e raça. Para o exame bacteriológico, as coletas foram realizadas com lâminas de bisturi estéreis e swabs em tubos estéreis com meio Stuart e refrigeradas em caixa térmica. Para análise histopatológica, os fragmentos foram fixados em formol a $10 \%$ e processados de forma rotineira para histologia e corados pela hematoxilina e eosina (HE). Entre 1.072 sistemas genitais avaliados, identificou-se 211 alterações. Os órgãos do sistema reprodutor mais acometidos foram os ovários $(65,3 \%)$, útero $(29,4 \%)$ e tubas uterinas $(5,3 \%)$. Nos ovários, a lesão mais frequente foi o cisto folicular $(34,1 \%)$; no útero a endometrite (9\%) e nas tubas uterinas, os cistos representaram (3,3\%). Outras lesões identificadas nos ovários foram: cisto luteinizado $(2,3 \%)$; tumor de células da granulosa $(0,5 \%)$; adenoma $(0,5 \%)$; agenesia unilateral $(0,5 \%)$, além de outras alterações de pouco significado clínico, como cistos paraovarianos $(15,6 \%)$ e corpo lúteo cístico $(11,8 \%)$. Nas tubas uterinas observou-se, além dos cistos tubo-ovarianos $(3,3 \%)$, hidrossalpinge $(1 \%)$, adenoma $(0,5 \%)$ e agenesia $(0,5 \%)$. As lesões uterinas foram endometrite $(9 \%)$, hidrometra $(2,3 \%)$; hiperplasia endometrial cística, abscesso e piometra $(1,4 \%$ cada); adenomiose, petéquias na serosa do útero e aplasia segmentar (1\% cada); dois úteros gravídicos, em início de gestação, apresentaram piometra $(0,9 \%)$, porém os fetos não apresentaram alterações; e pólipo uterino (0,5\%). Observou-se uma gestação ectópica com maceração fetal $(0,5 \%)$; a vaginite ocorreu em 0,5\%, e melanose endometrial em 8,5\%. Destaca-se a elevada incidência de cistos foliculares e endometrite que são doenças que reduzem a eficiência reprodutiva dos rebanhos, provocando infertilidade e perdas econômicas na produção.

TERMOS DE INDEXAÇÃO: Sistema reprodutor, ovelhas, abatedouro, frigorífico, Brasil, ovários, patologia, cistos foliculares, endometrite, ovinos.

\section{INTRODUCTION}

Brazil has the largest flock of sheep in Latin America, with approximately 18.9 million head, with the Northeast region and the state of Bahia occupying both the 1st place (IBGE 2018). In Brazil, sheep farming is extensive, with low technological investment and reduced zootechnical indicators, formed mainly by mixed or native sheep (Santos 2001, Osório \& Rassi 2011). However, the exploration of small ruminants is a growing activity and important for the Northeast region, mainly due to its adaptability to the arid and semi-arid regions of the country, characterized by long periods of drought, high temperatures, and shallow soils that are difficult to drain (Santos 2001, Leite \& Simplício 2005, Holanda Júnior \& Martins 2007, Monte 2008). It is essential to highlight that some studies have been carried out in slaughter sheep in Brazil to diagnose the main parasitic and infectious lesions, demonstrating that these studies are also important to reduce errors in slaughter condemnations in animals and guarantee the quality of products for consumers (Souza et al. 2011, Higino et al. 2013, Panziera et al. 2018). Reproductive efficiency is one of the most critical factors that promote productivity of sheep farming and economic viability, being essential for developing the herd. However, injuries to the reproductive system have significant limitations, which causes a drop in production (Agrawal 2010, Carvalho Júnior et al. 2010). Thus, diagnosis is necessary to prevent and control the main diseases that affect the sheep reproductive system.

The objective of this study was to evaluate the main changes found in the reproductive system of slaughtered sheep in slaughterhouses in the state of Bahia to identify the main injuries that cause losses in sheep farming and facilitate the development of prevention and control measures.

\section{MATERIALS AND METHODS}

The research was carried out in three slaughterhouses for sheep and goats in the state of Bahia according to the "Serviço de Inspeção Federal" and "Serviço de Inspeção Estadual". In the period from July 2018 to February 2019, 1,072 emaciated sheep were slaughtered. During slaughter, the evisceration (removal of internal organs) begins, i.e., the sheep reproductive system was sectioned to evaluate and collect material for anatomopathological and bacteriological examinations. In addition, epidemiological information related to the origin, age, and race of the animals was obtained. The changes were grouped into six categories based on macroscopic and microscopic descriptions: inflammatory, degenerative and proliferative changes, developmental abnormalities, and others.

Reproductive systems with lesions were analyzed macroscopically; then fragments were collected and fixed in $10 \%$ buffered formaldehyde, cleaved, processed routinely for histology, and stained with Hematoxylin and Eosin (HE). For the bacteriological examination, collections were performed with sterile scalpel slides and swabs in sterile tubes with Stuart medium and refrigerated in a thermal box. In addition, they were sent to the laboratory for isolation and identification of the etiological agent. The culture media used for primary seeding of uterine secretion were blood agar, chocolate agar, McConkey agar, and Thioglycolate. The biochemical tests used for bacterial identification were Rugai medium, citrate, malonate, urea, lysine, ornithine decarboxylase, Sulfide, Indole, Motility (SIM) medium, catalase, coagulase, Bile Esculin Agar (BEA), Brain Heart Infusion (BHI) Agar, $\mathrm{NaCl}$, and mannitol.

The statistics were based on descriptive analysis as a percentage of the frequency of macroscopic and histopathological changes in the results obtained.

\section{RESULTS}

During the studied period, 196 (18.3\%) samples of sheep with alterations in the reproductive system were analyzed, with $2.2 \%$ of the animals showing concomitant lesions; the total number of injuries corresponded to $19.6 \%(211 / 1,072)$. The animals were consisted of Dorper, Santa Inês, Mestiço, and no defined breeds, aged from six to 18 months and came from 22 municipalities in the state of Bahia, mainly in the North Central region. 
The most affected organs of the reproductive system were the ovaries $65.3 \%$ (138/211), followed by the uterus $29.4 \%$ $(62 / 211)$ and fallopian tubes $5.3 \%(11 / 211)$. In the ovaries, the most evident lesion was the follicular cyst 34.1\% (72/211); in utero, endometritis with $9.0 \%$ (19/211) and regarding the uterine tubes, cysts with $3.3 \%(7 / 211)$. The classification and number of the identified injuries are shown in Table 1.

\section{Ovarian changes}

In addition to the follicular cyst, the following lesions were diagnosed in the ovaries: paraovarian cysts $15.6 \%(33 / 211)$ and corpus luteum cysts $11.8 \%$ (25/211). Findings of little clinical significance were also diagnosed, such as: $2.3 \%$ luteinized cyst (5/211); granulosa cell tumor 0.5\% (1/211); adenoma $0.5 \%(1 / 211)$ and agenesis $0.5 \%(1 / 211)$.

In the follicular cyst, this cyst consisted of cystic dilatations filled with translucent fluid in the cortical region of ovary

Table 1. Distribution of 211 lesions in the reproductive system of 1072 sheep in slaughterhouses in the state of Bahia

\begin{tabular}{|c|c|c|}
\hline \multirow{2}{*}{ Alterations } & No. of cases & Frequency $(\%)$ \\
\hline & 138 & 65.3 \\
\hline \multicolumn{3}{|l|}{ Ovarian changes } \\
\hline Follicular cyst & 72 & 34.1 \\
\hline Paraovarian cyst & 33 & 15.6 \\
\hline Corpus luteum cyst & 25 & 11.8 \\
\hline Luteinized cyst & 5 & 2.3 \\
\hline Adenoma & 1 & 0.5 \\
\hline Granulosa cell tumor & 1 & 05 \\
\hline Agenesis & 1 & 0.5 \\
\hline Uterine changes & 62 & 29.4 \\
\hline Endometritis & 19 & 9 \\
\hline Melanosis & 18 & 8.5 \\
\hline Hydrometra & 5 & 2.3 \\
\hline Pyometra & 5 & 2.3 \\
\hline Abscess & 3 & 1.4 \\
\hline Cystic Endometrial Hyperplasia (CEH) & 3 & 1.4 \\
\hline Adenomyosis & 2 & 1.0 \\
\hline Petechiae in the serosa & 2 & 1.0 \\
\hline Segmental aplasia & 2 & 1.0 \\
\hline $\begin{array}{l}\text { Ectopic pregnancy with fetal } \\
\text { maceration }\end{array}$ & 1 & 0.5 \\
\hline Vaginitis & 1 & 0.5 \\
\hline Polyp & 1 & 0.5 \\
\hline Changes in uterine tubes & 11 & 5.3 \\
\hline Ovarian tube cyst & 7 & 3.3 \\
\hline Hydrosalpinx & 2 & 1.0 \\
\hline Agenesis & 1 & 0.5 \\
\hline Adenoma & 1 & 0.5 \\
\hline TOTAL & 211 & 100 \\
\hline
\end{tabular}

and absence of corpus luteum (Fig.1A). It was observed in the microscopic evaluation of follicular cysts a condition of ovaries with the absence of corpus luteum, follicles without visualization of oocytes; and it could also be described fibrosis and vacuolization in the cells of the teak layer or its absence; as well as a layer of cells of the degenerate, flattened, thin granulosa and, some folded cells and cellular debris. Regarding the paraovarian cysts, which were located close to the ovaries (Fig.1B), under the microscopy, they were covered by simple cuboidal epithelium and their wall composed of smooth muscle cells; and corpus luteum cysts, which, when cut, identified a cavity in the center filled with translucent material (Fig.1C). The luteinized cyst, also evaluated, showed areas with an absence of the granular layer, a layer of lutein cells in the cyst wall, with yellowish color.

Regarding proliferative changes, one case of granulosa cell tumor was diagnosed. It did not show macroscopic changes. Microscopically, the neoplastic proliferation of granulosa cells was observed, forming structures similar to follicles. Ovarian adenoma, a benign neoplasm, was characterized by cuboid cells arranged into cords and shaped like arboriform papillae.

Ovarian agenesis, a developmental abnormality characterized by the absence of the right ovary, occurred in a sample analyzed simultaneously with the absence of the right uterine tube.

\section{Uterine changes}

Uterine inflammatory changes were the most common lesion. In addition, the endometritis was the most observed lesion in the uterus with 9\% (19/211). The macroscopic characteristics of endometritis were organ distension, in some cases, from the uterine horns to the cervix, and when cut, with a yellowish-white and paste-like content (Fig.2A). Microscopic evaluation showed a marked inflammatory infiltrate composed of plasmocytes, macrophages, and neutrophils in the submucosa. In one case, in addition to endometritis, dilation and an increase in the number of endometrial glands were observed, which characterizes Cystic Endometrial Hyperplasia (CEH). Pyometra was diagnosed in 2.3\% (5/211). Macroscopically, it could be observed an enlarged uterus consisting of yellowish and paste-like content, and of more than $50 \%$ purulent exudate.

Among the evaluated cases, two pregnant uteri presented pyometra, where the fetus was located in one of the uterine horns, and the other had content formed by whitish striations. Microscopic analysis showed marked inflammation areas composed of plasma cells, macrophages, and neutrophils in the submucosa. In the bacteriological examination, of the nine samples sent for bacteriological examination, Escherichia coli was the most isolated microorganism (6/9), in addition to the following bacteria: Streptococcus sp. (1/9) and Pseudomonas aeruginosa (1/9). In a sample sent, there was no bacterial growth. The cases of abscesses were located in the uterine wall (Fig.2B) 1.4\% (3/211), both presented $1 \mathrm{~cm}$ in diameter, characterized by purulent or caseous material that varied from yellowish-white or greenish, with odor or odorless, surrounded by a fibrous capsule. Under the microscopy, the abscess was located in the muscular and serous tissue of the uterine wall. A fibrous connective tissue capsule was observed, with moderate inflammatory infiltrate composed of lymphocytes, macrophages, and plasmocytes, and around the area of inflammatory infiltrate necrosis formed by degenerated 
macrophages and neutrophils. In the vagina, it could be observed vaginitis in $0.5 \%(1 / 211)$ of the animals. Microscopic evaluation showed moderate mixed inflammatory infiltrate composed of lymphocytes, plasmocytes, and neutrophils located under the Basement Membrane (BM).

In hydrometra $2.3 \%(5 / 211)$ of degenerative lesion and the second major pathology were diagnosed, the uterus was dilated and cut, and it was replete with clear fluid accumulation in the lumen. Microscopy showed dilation of the endometrial glands.

With respect to the $\mathrm{CEH}(1.4 \%, 3 / 211)$, among the proliferative lesions, there was an intense proliferation of endometrial glands with preservation of the morphological pattern. Adenomyosis in 1\% (2/211) was identified in the microscopic analysis by distributing the endometrial glands among the myometrial muscle fibers without macroscopic changes. The uterine polyp $(0.5 \%, 1 / 211)$ was diagnosed by a pedunculated formation. Microscopically, it had a digitiform shape with the center filled with fibrous connective tissue.

The developmental abnormality was related to total segmental aplasia in 1\% (2/211), absence of the formation of a segment of the uterus, the animals presented only one uterine horn. Melanosis in 8.5\% (18/211) was characterized by pigmentation distributed in the endometrium areas (Fig.2C). Microscopy showed the distribution of black pigment in the submucosa and loose connective tissue of the endometrium.
Regarding other changes, ectopic pregnancy with fetal maceration was observed in one case, $0.5 \%(1 / 211)$. A whole normal uterus was found, but it was accompanied and connected to the organ removed from the abdominal cavity, a bag of encapsulated fatty tissue, and in its interior bone structures, a macerated fetus.

\section{Fallopian tubes changes}

The pathologies in the uterine tube were as following: tube-ovarian cyst in 3.3\% (7/211), hydrosalpinx in 1\% (2/211), adenoma in $0.5 \%(1 / 211)$ and agenesis in $0.5 \%(1 / 211)$. Macroscopy of the cysts was located on the external surface of the wall (Fig.3A), close to the insertion of mesosalpinx. The walls were composed of simple cylindrical ciliated epithelium, basement membrane, and smooth muscle on microscopic examination. Hydrosalpinx, an inflammatory disease, was identified by the unilateral dilation of $0.9 \mathrm{~cm}$ in diameter of the lumen of uterine tube by liquid content (Fig.3B), under microscopy, absence of folds in the mucosa and, due to distension, the cells exhibited a flattened morphology. The developmental abnormality observed in one case was agenesis of the right uterine tube (Fig.3C). A proliferative lesion found in this organ was the adenoma. Microscopically, cuboid cells were observed grouped in cords and formed the shape of arboriform papillae.
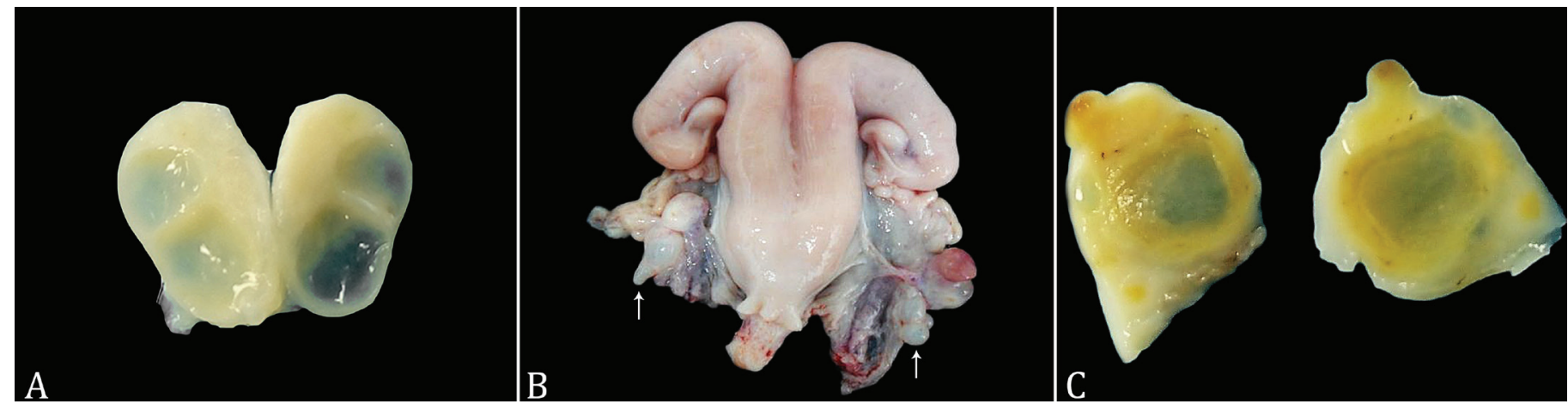

Fig.1. Sheep reproductive system. (A) Follicular cysts. Cystic dilations filled with translucent fluid in the cortical region of the ovary and absence of corpus luteum. (B) Bilateral paraovarian cysts (white arrows). Mesometrial cysts. (C) Corpus luteum cysts. Cutting surface, a cavity in the center is identified, filled with translucent material.

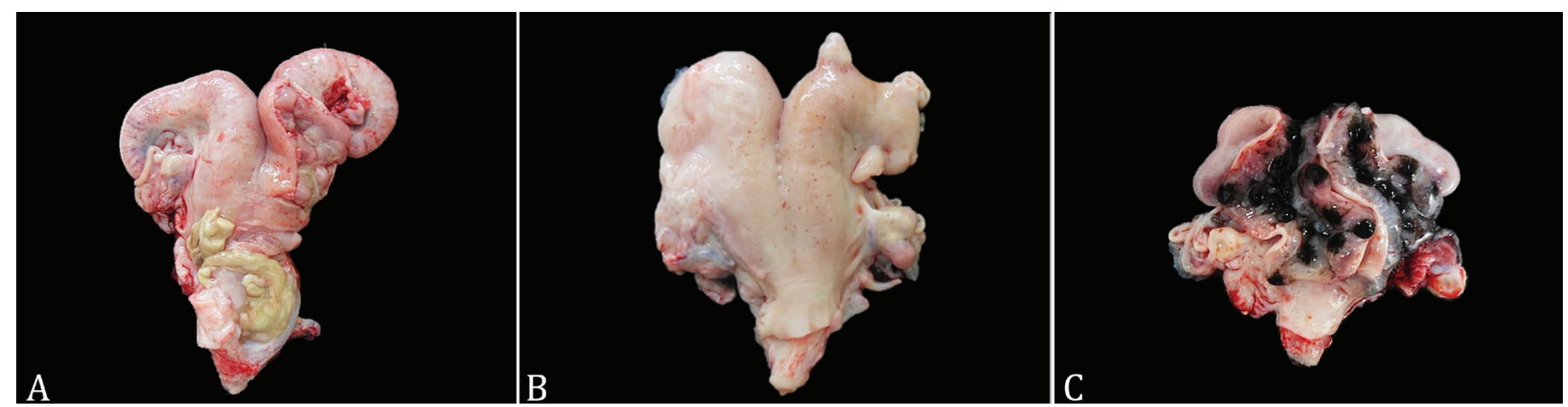

Fig.2. Sheep reproductive system. (A) Endometritis - an enlarged organ, mainly in the cervix. When cut, it could be observed yellowishwhite content. (B) Adherence and fibrosis of the uterine horn, fallopian tube, and left ovary. Petechiae are observed distributed from the body of the uterus to the horns, with a prominent protruding abscess on the right bottom of the body of the uterus (white arrow). (C) Melanosis. Caruncular pigmentation and edema. 

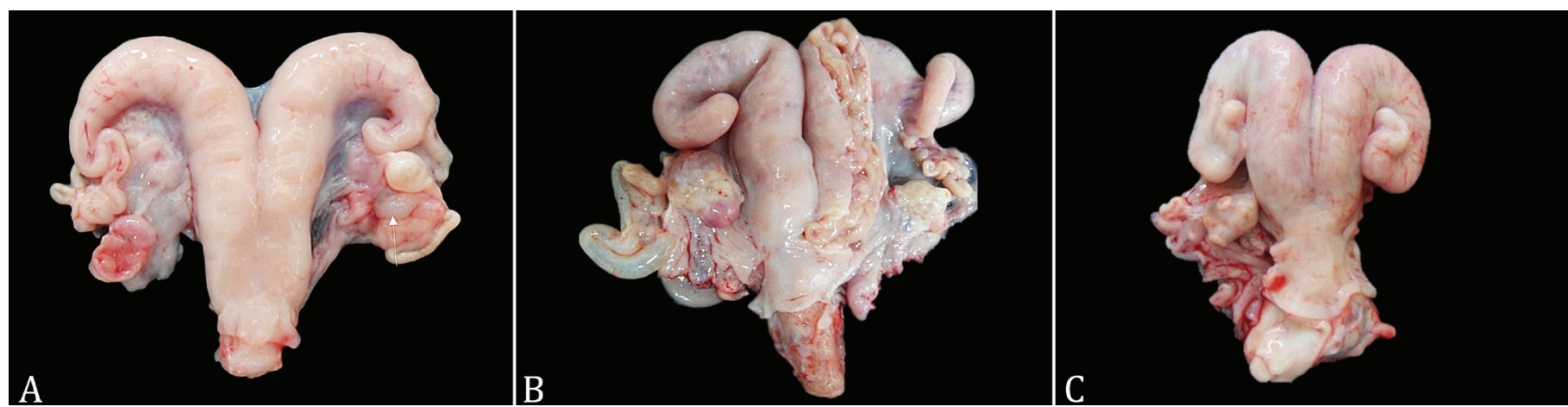

Fig.3. Sheep reproductive system. (A) Right ovarian tube cyst (white arrow). (B) Distension of the uterine tube (hydrosalpinx) with liquid and translucent content, $0.9 \mathrm{~cm}$ in diameter (arrow). (C) Agenesis of the ovary and right uterine tube.

\section{DISCUSSION}

In this study, injuries occurred in $19.5 \%(211 / 1,072)$ of the cases, similar to that observed in other studies of the same nature carried out in the state of Ceará (20.35\%) (Santa Rosa et al. 1987), in Iran (25.8\%) (Moghaddam \& Gooraninejad 2007) and 16.6\% (Khodakaram-Tafti \& Davari 2013), India (14.98\%) (Agrawal 2010) and Himalayas (19.47\%) (Sharma et al. 2014).

The ovaries were the most affected organs, with the follicular cyst being the most relevant lesion in this study, presenting results similar to the research by Sharma et al. (2014) as following: $13.56 \%$ of lesions in the ovaries was registered (Santa Rosa et al. 1987), in the studies by Moghaddam \& Gooraninejad (2007), the highest rates of abnormalities were also in the ovaries consisting of $20.1 \%$, with a predominance of follicular cysts. The etiopathogenesis of follicular cysts may be related to disorders in the Hypothalamic-PituitaryGonadal (HPG) axis. If the gonadotropin-releasing hormone $(\mathrm{GnRH})$ is not released from the hypothalamus due to estradiol stimulation, or the anterior pituitary does not release the Luteinizing Hormone (LH), they will cause cyst formation and an increase in progesterone (Silva et al. 2002). The absence of LH receptors in the mature follicle or deficiency of GnRH receptors in the pituitary gland is also related to cyst formation (Santos et al. 2016). Similar results were identified in the ovaries of cows in the microscopic evaluation, such as the absence of oocyte, pellucid zone, and granulosa cells, in addition to internal teak fibrosis and partial luteinization of the cystic wall (Ramos et al. 2010).

The granulosa cell tumor is an ovarian neoplasm of the sexual cords, initially formed by cells similar to the follicle granulosa cells (Santos et al. 2016), and it could be observed in a sheep in this study. Similar data were described in three cows, in which in one case, no macroscopic changes were observed. However, microscopy showed rosette formation in the granulosa cells (Hatipoglu et al. (2002).

The adenoma, a lesion identified in one case in this research, is characterized as an epithelial neoplasia derived from the germinal epithelium, from the Subsurface Epithelial Structures (SES), or the rete ovarii. It did not occur in similar studies by other authors (Santa Rosa et al.1987, Moghaddam \& Gooraninejad 2007, Agrawal 2010, Khodakaram-Tafti \& Davari 2013, Sharma et al. 2014). Under the microscopic examination, they tend to have cuboid cells grouped into cords, with a pycnotic nucleus, a sparse cytoplasm grouped in the shape of arboriform papillae (Akihara et al. 2007).

Among the findings with little clinical significance, the paraovarian cyst represented $15.6 \%$ and the corpus luteum cysts $11.8 \%$. In a study conducted by Khodakaram-Tafti \& Davari (2013), it could be found $0.9 \%$ paraovarian cysts in sheep, and in a research performed with cows, this cyst was identified in eight cases (Hatipoglu et al. 2002). The corpus luteum cyst is characterized by the formation of a cystic cavity in the center of the lutein tissue, present in $25 \%$ of the corpus luteum (Santos et al. 2016). In studies with cows, 0.74\% (Ramos et al. (2010) and 2.51\% (Hatipoglu et al. 2002) of corpus luteum cysts were identified.

Endometritis was the most identified uterine pathology in the present study, comprising $9 \%$ of changes in the uterus characterized by yellowish-white mucus. In other studies carried out with sheep, endometritis was predominant in $2.93 \%$ (Khodakaram-Tafti \& Davari 2013) and $0.34 \%$ of cases (Agrawal 2010). In the macroscopic evaluation, the presence of mucus, which can vary from serous to purulent and also from varying degrees of purulent striations (Schlafer \& Miller 2007), hyperemia and endometrial edema (Santos et al. 2016). Microscopically, an inflammatory infiltrate formed by lymphocytes, histiocytes, and neutrophils in periglandular and perivascular regions could be identified, and it was possible to verify fibrosis in these areas as well (Bonnett et al. 1993, Bondurant 1999). It is a frequent alteration in the uterus of several domestic females that reduces reproductive efficiency of herds, increases the occurrence of estrous repetition and birth interval, and causes a drop in milk production (Nascimento \& Santos 2011).

Pyometra, acute or chronic infection of the uterus, with deposition of purulent material and persistence of a corpus luteum, can occur due to endometritis or metritis (Dow 1960, Sheldon et al. 2008, Schlafer \& Foster 2015). When it forms purulent exudate, infection is usually caused by Staphylococcus sp. and Streptococcus sp. (Johnson 2006, Foster 2013, Schlafer \& Foster 2015). In this work, the bacteria Escherichia coli and Streptococcus sp could be detected.

Hydrometra was the second pathology diagnosed in this research with $2.3 \%$. It is described as the accumulation of clear and aseptic fluid in the lumen of the uterus (Nascimento \& Santos 2011, Foster 2013), which may be concomitant to the development of endometrial hyperplasia (Santos et al. 2016), as well as being characterized as widespread pathology in 
goats and also diagnosed in sheep (Bretzlaff 1993, Wittek et al. 1997). If the hydrometra or mucometra are chronic, they cause atrophy of the endometrium, contributing to subfertility or infertility (Smith 1980, Schlafer \& Miller 2007, Foster 2013, Schlafer \& Foster 2015). Other work performed could register $0.3 \%$ (Moghaddam \& Gooraninejad 2007), $0.15 \%$ (Khodakaram-Tafti \& Davari 2013) and $2.99 \%$ of this pathology (Agrawal 2010).

In this study, the CEH was observed in $1.4 \%$ of the diseases. According to Santa Rosa et al. (1987), in a study carried out with sheep in the state of Ceará, this disease was identified in $0.85 \%$ of the animals; in another survey in Iran, it was identified in $0.15 \%$ (Khodakaram-Tafti \& Davari 2013); and in a study performed with cattle, eight cows showed CEH (Hatipoglu et al. 2002). CEH is caused by hyperestrogenism in ruminants, usually due to the ingestion of phytoestrogenic plants in sheep and goats, and also owing to follicular cysts or granulosa cell tumors in cows, which can promote mucometra, hydrometra, or pyometra (Santos et al. 2016). Macroscopically, a slight, irregular, or diffuse thickening of the endometrium is observed (Foster 2013). It is usually associated with ovarian neoplasms (Maclachilan 1987, Cardilli et al. 2007). Microscopic findings are characterized by the proliferation of endometrial glands, which can preserve their morphological pattern or be dilated, cystic, and covered by a cuboidal epithelium (Pereira et al. 2015).

The accumulation of melanin in the uterine caruncles and caruncular pigmentation is a finding with little clinical significance that mainly affects black-skinned sheep, with a greater tendency in animals with pigmentation on the face. This heterotopic pigmentation occurs due to the accumulation of melanin in a not pigmented organ, such as the lung, but can occur in other organs. This pathology is developed owing to the irregular migration of melanocytes from the neural groove but does not interfere with the function of the organs (Santos et al. 2016). In the present study, 18 cases of melanosis were diagnosed, corresponding to $8.5 \%$ of uterine lesions. Other studies have also recorded this finding, where hyperpigmentation has been reported due to deposition of melanin in the uterine caruncles and the intercaruncular endometrium (Smith et al. 1999, Khodakaram-Tafti \& Davari 2013).

In this study, $3.3 \%$ of cysts located in the fallopian tube were diagnosed. According to Santos et al. (2016), it is located on the external surface of the wall and, in most cases, adjacent to the insertion of the mesosalpinx, which can cause stenosis of the lumen by compression. When located in the fimbriated region of the infundibulum, they cause infertility by impairing the oocyte uptake.

Hydrosalpinx represented $1 \%$ of pathologies. The oviduct inflammatory process may cause this degenerative alteration, characterized by the distension of the lumen of uterine tubes by the accumulation of transudate (Santos et al. 2016). It can also occur due to adhesions of the uterine tube to nearby organs (Grunert et al. 2005). In other studies, this lesion was observed with a variation in the incidence of $1.69 \%$, where the cases of hydrosalpinx were bilateral and affected the middle portion of the fallopian tubes (Santa Rosa et al. 1987); it could be observed in $1.1 \%$ (Moghaddam \& Gooraninejad 2007 ) and $0.35 \%$ in cows located in the right uterine tube (Lenzi 2017); and 0.36\% (Hatipoglu et al. 2002).
A case of adenoma was also diagnosed in the fallopian tube. Epithelial and mesenchymal neoplasms of this organ are rare in domestic animals. There are reports of benign epithelial neoplasms in dogs (Pierezan et al. 2016, Gelberg \& McEntee 1986, Marino et al. 2007). The principal differential diagnosis of adenoma is related to the adenocarcinoma, and implantation in other organs and peritoneal cavities should be considered (Gelberg \& McEntee 1986, Pierezan et al. 2016).

\section{CONCLUSION}

Infertility and reduction in reproductive efficiency of sheep can be caused mainly by follicular cysts, endometritis, and cysts in the uterine tubes. These important pathologies interfere in the productivity of sheep farming. Early diagnosis of these changes prevents probable losses in production.

Acknowledgments.- To the "Serviço de Inspeção Federal" (SIF) and "Serviço de Inspeção Estadual" (SIE), and also to the slaughterhouse professionals, the "Coordenação de Aperfeiçoamento de Pessoal de Nível Superior" (CAPES) for granting the first author's scholarship, and the "Universidade Federal da Bahia" (UFBA).

Conflict of interest statement.- The authors have no competing interests.

\section{REFERENCES}

Agrawal J.K. 2010. Genital status and reproductive disorders in small ruminantsan abattoir investigation. Doctoral Dissertation, Chaudhary Sarwan Kumar Himachal Pradesh Krishi Vishvavidyalaya Palampur, India, 80p.

Akihara Y., Shimoyama Y., Kawasako K., Komine M., Hirayama K., Kagawa Y., Omachi T., Matsuda K., Okamoto M., Kadosawa T. \& Taniyama H. 2007. Inmunohistochemical evaluation of canine ovarian tumors. J. Vet. Med. Sci. 69(7):703-708. <https://dx.doi.org/10.1292/jvms.69.703><PMid:17675800>

Bondurant R.H. 1999. Inflammation in the bovine female reproductive tract. J. Animal Sci. 77(supl.2):101-110.<https://dx.doi.org/10.2527/1999.77suppl_2101x> <PMid:15526785>

Bonnett B.N., Martins S.W. \& Meek A.H. 1993. Associations of clinical findings, bacteriological and histological results of endometrial biopsy with reproductive performance of postpartum dairy cows. Prev. Vet. Med. 15(2/3):205-220. <https://dx.doi.org/10.1016/0167-5877(93)90114-9>

Bretzlaff K.N. 1993. Development of hydrometra in a ewe flock after ultrasonography for determination of pregnancy. J. Am. Vet. Med. Assoc. 203(1):122-125. <PMid:8407445>

Cardilli D.J., Toniollo G.H., Mostachio G.Q., Motheo T.F., Lima I.G. \& Vicente W.R. 2007. Disgerminoma ovariano em cadela: relato de caso. Clín. Vet. 66:64-66.

Carvalho Júnior C.A., Xavier M.N., Costa L.F. Silveira S.S., Sant'Anna F.M., Borges A.M., Gouveia A.M.G. \& Santos R.L. 2010. Agentes infecciosos que podem promover infertilidade em machos da espécie ovina. Rev. Bras. Reprod. Anim. 34(3):160-167.

Dow C. 1960. The cystic hyperplasia-pyometra complex in the bitch. Doctoral Dissertation, University of Glasgow, United Kingdom. 72p.

Foster R.A. 2013. Sistema Reprodutivo da Fêmea, p.1088-1099. In: McGavin M.D. \& Zachary J. F. Bases da Patologia Veterinária. 5. ed. Elsevier, Rio de Janeiro.

Gelberg H.B. \& Mcentee K. 1986. Pathology of the canine and feline uterine tube. Vet. Pathol. 23(6):770-775. <https://dx.doi.org/10.1177/030098588602300617> <PMid:3811142>

Grunert E., Birgel E.H., Vale W.G. \& Birgel Junior E.H. 2005. Patologia e Clínica da Reprodução dos Animais Domésticos: Ginecologia. São Paulo: Varela. 551p. 
Hatipoglu F., Kiran M.M., Ortatatli M., Erer H. \& Çiftçi M.K. 2002. An abattoir study of genital pathology in cows: I. Ovary and oviduct. Rev. Méd. Vet., 153(1):29-33.

Higino S.S.S., Pinheiro S.R., Rocha V.C.M., Souza G.O., Portela R.A., Alves C.J., Vasconcellos S.A., Dib C.C., Rosário T.R., Melville P.A. \& Azevedo S.S. 2013. Tuberculose em caprinos e ovinos abatidos no semiárido da Paraíba, Brasil. Arqs. Inst. Biológico. 80(3):281-287. <https://dx.doi.org/10.1590/ S1808-16572013000300004>

Holanda Júnior E.V. \& Martins E.C. 2007. Análise da produção e do mercado de produtos caprinos e ovinos: o caso do território do sertão do Pajeú em Pernambuco. Anais VII Congresso Brasileiro de sistemas de produção, Fortaleza, CE, p.5-6. (Resumo)

IBGE. Instituto Brasileiro de Geografia e Estatística. 2018. Pecuária: Efetivos / Rebanhos. Available at <www.sidra.ibge.gov.br> Accessed on Aug. 25, 2019.

Johnson C.A. 2006. Distúrbios do sistema reprodutivo, p.811-912. In: Nelson R.W. \& Couto C.G. Medicina Interna de Pequenos Animais. $3^{\mathrm{a}}$ ed. Elsevier, Rio de Janeiro.

Khodakaram-Tafti A. \& Davari A. 2013. Congenital and acquired abnormalities of reproductive tract of non-pregnant ewes slaughtered in Fars province, Iran. Iran. J. Vet. Res. 14(2):140-144. <https://dx.doi.org/10.22099/ IJVR.2013.1588>

Leite E.R. \& Simplício A.A. 2005. Sistema de produção de caprinos e ovinos de corte para o Nordeste brasileiro: Importância econômica. [S.I.]: Embrapa. Disponível em <http://www.cnpc.embrapa.br/importancia.htm>. Acesso em: 01 dez. 2018.

Lenzi G.P. 2017. Caracterização macroscópica, microscópicas e ultrassonográfica de patologias do trato reprodutivo de fêmeas bovinas provenientes de abatedouro. Dissertação de Mestrado, Universidade Federal de Minas Gerais, Belo Horizonte. 30p.

Maclachilan N.J. 1987. Ovarian disorders in domestic animals. Environ. Health Perspec. 73:27-33. <https://dx.doi.org/10.1289/ehp.877327> $<$ PMid:3665869>

Marino G., Quartuccio M., Cristarella S., Nicòtina P.A. \& Zanghì A. 2007. Adenoma of the uterine tube in the bitch: two case reports. Vet. Res. Commu. 31(supl.1):173-175. <https://dx.doi.org/10.1007/s11259-007-0025-4> <PMid:17682868>

Moghaddam A. \& Gooraninejad S. 2007. Abattoir survey of gross abnormalities of the ovine genital tracts in Iran. Small Rum. Res. 73(1/3):259-261. <https://dx.doi.org/10.1016/j.smallrumres.2006.10.022>

Monte H.L.B.D. 2008. Gestão técnico-econômica da produção de leite de cabra nos cariris paraibanos. Tese de doutorado, Universidade Federal da Paraíba, Areia, 211p.

Nascimento E.F. \& Santos L.S. 2011. Patologia da Reprodução dos Animais Domésticos. 3eed. Guanabra Koogan, Belo Horizonte, p.174.

Osório A. \& Rassi L. 2011. A carne ovina e o abate clandestino: quais são as causas da informalidade? Disponível em: <http://www.farmpoint.com.br/ cadeia-produtiva/espaco-aberto/a-carne-ovina-e-o abate-clandestino-quaissao-as-causas-da-informalidade-70459n.aspx> Acesso em: 10 fev. 2019.

Panziera W., Vielmo A., De Lorenzo C., Heck L.C., Pavarini S.P., Sonne L., Soares J.F. \& Driemeier D. 2018. Caracterização das lesões parasitárias de ovinos observadas na linha de abate. Pesq. Vet. Bras. 38(8):1491-1504. <https://dx.doi.org/10.1590/1678-5150-pvb-5549>

Pereira J.V.T.N., Pinho R.O., Meneses R.M., Mendes V.R.A., Pereira E.C.M. \& Guimarães J.D. 2015. Hiperplasia endometrial cística e hidrossalpinge associada à cisto folicular em bovinos. Rev. Bras. Med. Vet. 37(1):1-6.

Pierezan F., Trost M.E. \& Barros C.S.L. 2016. Uterine tube adenoma in a bitch. Brazilian J. Vet. Pathol., 9(1):27-30.

Ramos E.M., Oliveira C.M., Silva S.M.M.S., Silva L.S., Maruo V.M., Minharro S. \& Cavalcante T.V. 2010. Alterações ovarianas em vacas zebuínas criadas na Amazônia Oriental. Rev. Cient. Eletr. Med. Vet. 8(15):1-18.

Santa Rosa J., Santos L.F.L. \& Simplício A.A. 1987. Alterações anátomohistopatológicas no sistema reprodutivo de ovelhas adultas, não prenhes, no município de Sobral, Ceará. Rev. Bras. Reprod. Anim. 11(14):179-186.

Santos R.L. 2001. Diagnóstico da cadeia produtiva da caprinocultura de corte no estado da Bahia. 2001. Monografia de Especialização em Administração em Agribusiness, Faculdade São Francisco de Barreiras, Barreiras. 40p.

Santos R.L., Nascimento E.F. \& Edwards J.F. 2016. Sistema Reprodutivo Feminino, p.1206. In: Santos R.L. \& Alessi A.C. Patologia Veterinária. 2a ed. Roca, Rio de Janeiro.

Schlafer D.H. \& Foster R.A. 2015. Female genital system, p.358-464. In: Maxie M.G., Jubb K.V.F., Kennedy P.C. \& Palmer's N.C. Pathology of Domestic Animals. Vol.3. 6⿳⺈ ${ }^{\underline{a}}$ ed. Elsevier, St. Louis.

Schlafer D.H. \& Miller R.B. 2007. Female genital system, p.424-564. In: Jubb K.V.F., Kennedy P.C. \& Palmer's N.C. Pathology of Domestic Animals. Vol. 3. 5ed. Elsevier Saunders, Philadelphia.

Sharma A., Kumar P., Singh M. \& Vasishta M.K. 2014. Reproductive health status of north western Himalayan Gaddi sheep: An abattoir study. Open Vet. J. 4(2):103-106. <PMid:26623348>

Sheldon I.M., Willians E.J., Miller A.N.A., Nash D.M. \& Herath S. 2008. Uterine diseases in cattle after parturition. Vet. J. 176(3):115-121.<https://dx.doi. org/10.1016/j.tvjl.2007.12.031><PMid:18329302>

Silva J.R.V., Ferreira M.A.L., Costa S.H.F., Santos R.R., Carvalho F.C.A., Rodrigues A.P.R., Lucci C.M., Báo S.N. \& Figueiredo J.R. 2002. Degeneration rate of preantral follicles in the ovaries of goats. Small Ruminant Res. 43(3):203-209. <https://dx.doi.org/10.1016/S0921-4488(02)00017-2>

Smith K.C., Parkinson T.J. \& Long S.E. 1999. Abattoir survey of acquired reproductive abnormalities in ewes. Vet. Rec. 144(18):491-496. <https:// dx.doi.org/10.1136/vr.144.18.491><PMid:10358887>

Smith M.C. 1980. Caprine production, p.969-1004. In: Morrow D.A. Current Therapy in Theriogenology: Diagnosis, Treatment and Prevention of Reproductive Diseases in Animals. WB Saunders, Philadelphia.

Souza M.F., Carvalho A.Q., Garino Jr F. \& Riet-Correa F. 2011. Linfadenite caseosa em ovinos deslanados abatidos em um frigorífico da Paraíba. Pesq. Vet. Bras. 31(3):224-230. <https://dx.doi.org/10.1590/S0100736X2011000300007>

Wittek T., Richter A., Erices J. \& Elze K. 1997. Incidence, diagnosis, therapy and subsequent fertility in goats with hydrometra. Tierarztl. Prax. Ausg. G. Grosstiere/Nutztiere. 25(6):576-582. <PMid:9451762> 
